\title{
Reproducibility of the measurement of central corneal thickness in healthy subjects obtained with the optical low coherence reflectometry pachymeter and comparison with the ultrasonic pachymetry
}

\author{
Evaluación de la reproducibilidad en la medición del grosor corneal central con el \\ paquímetro de reflectometría óptica de baja coherencia y comparación con el paquímetro \\ ultrasónico en sujetos sanos
}

Manuel Garza-Leon ${ }^{1,2 *}$, Eduardo Plancarte-Lozano ${ }^{1}$ Agustín Del Valle-Penella', María de Lourdes Guzmán-Martínez ${ }^{1}$ and Andrés Villarreal-González'

${ }^{1}$ Fundación Destellos de Luz; ${ }^{2}$ Medical Sciences Head Office, Division of Health Sciences, Universidad de Monterrey. Monterrey, N.L., Mexico

\begin{abstract}
Background: Corneal pachymetry is widely used for refractive surgery and follow up in keratoconus, accurate measurement is essential for a safe surgery. Objective: To assess intraobserver reliability of central corneal thickness (CCT) measurements using optical low-coherence reflectometry (OLCR) technology and its agreement with ultrasonic pachymeter (US). Method: Randomized and prospective comparative evaluation of diagnostic technology. One randomly healthy eye of subjects was scanned three times with both devices. Intraobserver within-subject standard deviation (Sw), coefficient of variation (CVw) and intraclass correlation coefficient (ICC) were obtained for reliability analysis; for study agreement, data were analyzed using the paired-sample $t$ test and the Bland-Altman LoA method. The mean of three scans of each equipment was used to assess the LOA. Results: The study enrolled 30 eyes of 30 subjects with average age of $28.70 \pm 8.06$ years. For repeatability, the Sw were 3.41 and $5.96 \mu$, the intraobserver CVW was 2 and $4 \%$ and ICC 0.991 and 0.988 , for OLCR and US respectively. The mean CCT difference between OLCR and US was $8.90 \pm 9.03 \mu$ (95\% confidence interval: 5.52-2.27 $\mu$ ), and the LoA was $35.40 \mu$. Conclusions: OLCR technology provided reliable intraobserver CCT measurements. Both pachymetry measurements may be used interchangeably with minimum calibration adjustment.
\end{abstract}

KEY WORDS: Corneal thickness. Ultrasound pachymetry. Optical low-coherence reflectometry. Reproducibility.

\section{Resumen}

Antecedentes: La paquimetría corneal es ampliamente utilizada para la cirugía refractiva y el seguimiento de pacientes con queratocono. La medición exacta es esencial para una cirugía refractiva segura. Objetivo: Evaluar la reproducibilidad intraobservador en la medición del grosor corneal central (GCC) utilizando reflectometría óptica de baja coherencia (OLCR) y su concordancia con la paquimetría ultrasónica. Método: Estudio prospectivo, comparativo y aleatorizado de una tecnología diagnóstica. Se midió de forma aleatorizada un ojo de cada sujeto en tres ocasiones con ambos equipos. Para el análisis de fiabilidad se obtuvieron la desviación estándar (DE) intrasujeto, el coeficiente de variación (CV) y el coeficiente de correlación 
intraclase (CCl). Para el estudio de concordancia se analizaron los datos usando una prueba t pareada simple, además de los límites de acuerdo de Bland-Altman (LA). Para la evaluación de los LA se utilizó el promedio de las tres mediciones de cada equipo. Resultados: El estudio incluyó 30 ojos de 30 sujetos con una edad promedio de $28.70 \pm 8.06$ años. Para la repetibilidad, la DE intrasujeto fue de 3.41 y $5.96 \mu$, el CV del 2 y el $4 \%$, y el CCl de 0.991 y 0.988, para el OLCR y el paquímetro ultrasónico, respectivamente. La diferencia del GCC promedio entre el OLCR y el paquímetro ultrasónico fue de 8.90

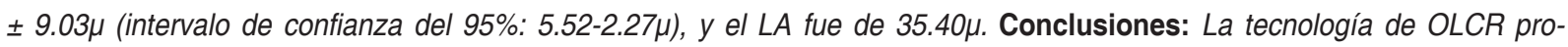
porciona medidas del GCC intraobservador fiables. Ambas mediciones paquimétricas pueden usarse de forma intercambiable con mínimos ajustes de calibración.

PALABRAS CLAVE: Grosor corneal. Paquimetría ultrasónica. Reflectometría óptica de baja coherencia. Reproducibilidad.

\section{Introduction}

Corneal pachymetry, an examination that measures the thickness of the cornea, has multiple uses in the field of ophthalmology. In refractive surgery, it is used to decide on the technique and determine the number of diopters that can be corrected ${ }^{1}$. Pachymetry allows assessing the state of the cornea in contact lenses users, since their chronic use is associated with edema and thinning. Corneal thickness measurement allows more accurate intraocular pressure calculation, with thickness being a corrective factor, since a thick cornea offers greater resistance than a thin one and is a risk factor for developing glaucoma in some ethnic groups ${ }^{2}$.

Central corneal thickness (CCT) can be measured using different technologies, but the standard method remains measurement by ultrasonic pachymetry due to its high degree of intraobserver repeatability and consistency with other ultrasonic equipment3,4; however, the need to manipulate the equipment and contact with the corneal surface make it unattractive for transoperative use.

Wavelight ${ }^{\circledR}$ Ex500 was launched onto the market in 2009, and in 2011, the Food and Drug Administration authorized its use in the USA. One of Wavelight ${ }^{\circledR}$ Ex500 Excimer Laser changes with regard to its preceding model is the introduction of pre, trans- and postoperative pachymetry measurement. For this purpose, Wavelight ${ }^{\circledR}$ Ex500 Excimer Laser added a non-contact pachymeter integrated to its platform, which is based on optical low-coherence reflectometry (OLCR) technology and allows both static and dynamic CCT measurement during ablation, thus conferring greater safety to the surgical procedure.

OLCR pachymetry is currently used by some diagnostic instruments, out of which one of the most widely studied is the Lensar ${ }^{\circledR}$ LS 900 ocular biometer (Haag Streit, Germany), which has been compared against other available technologies, such as ultrasonic pachymetry $^{5-7}$, optical coherence tomography $y^{5,7,8}$ and topography with Scheimpflug imaging, ${ }^{5,9-11}$, with varying results. So far, the only study comparing the Wavelight ${ }^{\circledR}$ Ex500 pachymeter with the ultrasonic one is the one carried out by Soeken, et al. ${ }^{12}$, who studied 50 eyes of 26 patients operated with laser-assisted in situ keratomileusis (LASIK) and found a difference of $0.78 \mu$.

In this study, the central pachymetry measurement obtained with a new instrument, Wavelight ${ }^{\circledR}$ Ex500 Excimer Laser, was compared against current standard method, Pachette 3 Model 555 ultrasonic pachymeter, with the variability between both methods thus being obtained. The purpose of this comparison was to observe whether the difference between both instruments is statistically and clinically significant. In addition, within this research, the repeatability of both instruments was assessed by performing three measurements, which were compared with each other.

Our hypothesis is that there will be a difference of less than $10 \mu$ between both instruments, a clinically poorly significant value.

\section{Method}

In this prospective, cross-sectional, observational study, healthy volunteers older than 18 years were recruited, and underwent a complete ophthalmological examination in order to rule out any corneal pathology that might modify the results of the studies. Patients with a history of eye disease, trauma or surgery, and those who wore contact lenses were excluded. The purposes of the study, as well as the risks and discomforts related to it were explained, and the subjects subsequently signed an informed consent document. Prior to the start of the study, approval by the Universidad de Monterrey Ethics Committee was obtained.

\section{Sample size calculation}

Initially, a pilot study was conducted with 15 patients and, with the obtained results, sample size calculation 
was made based on the comparison of paired means with a mean difference of $5 \mu$ to be detected, a power of $90 \%$ and a $95 \%$ level of confidence, which yielded a sample of 28 patients.

\section{Central corneal thickness measurement}

The eye to be studied was randomized and all examinations were carried out between 15:00 and 18:00 hours. The volunteers had at least 6 hours of wakefulness with the purpose to minimize corneal thickness diurnal variation ${ }^{13}$. An expert observer carried out all measurements, and three measurements were carried out with each equipment. Between each measurement, there was a 30-second waiting interval and patients were asked to blink normally. Statistical analysis was carried out using the averages of all three measurements.

The order of examinations was always the same: the first equipment to be used was Wavelight ${ }^{\circledR}$ Ex500 Excimer Laser; subsequently a drop of anesthetic was applied again and the ultrasonic pachymeter measurement was carried out. Even when using anesthetics is not necessary for the procedure with Wavelight ${ }^{\circledR}$ Ex500, a drop of topical anesthetic (Ponti Ofteno $囚$, Laboratorios Sophia, Guadalajara, Mexico) was applied prior to the first measurement with each equipment in order to avoid a change in the measurement due to the use of anesthetic only during ultrasonic pachymetry ${ }^{14,15}$.

Measurement in both instruments was carried out in accordance with the guidelines provided by the commercial houses that manufacture them. In both cases, the operator kept the patient's eyelids open with the fingers, and for the Wavelight ${ }^{\circledR}$ Ex500 Excimer Laser equipment, the patient was asked to look at the fixation point to proceed with the measurement. With the purpose to prevent for the measurement with the ultrasonic pachymeter (Pachette 3, Model 555, DGH Technology, Inc.) to be made in another area of the cornea, the patient was asked to look at the laser fixation point and the centering of the measurement was guided by the reflection of this point.

\section{Statistical analysis}

Except when otherwise specified, all analyses were performed using the SPSS (version 21.0, IBM) and Excel 2007 (Microsoft, Redmond, Washington, USA) programs. Normality of distribution of all anatomical data was confirmed with Kolmogórov-Smirnov test, and parametric tests were used for data analysis.
Intraobserver repeatability was assessed using three indices:

- Intraclass correlation coefficient (ICC). ICCs were calculated for each equipment by dividing the variance between subjects by total variance (ICC $=\sigma 2 b / \sigma 2 b+\sigma 2 w)$. Inter-subject variance indicates the differences between individuals, while intra-subject variance reflects the differences between measurements made to the same individual (measurement error). Therefore, ICC estimates the proportion of total variance that is attributable to real differences between subjects ("true" variance), and it is 1 when there is no error in the measurements of a single individual, thus reflecting high repeatability.

- Intra-subject standard deviations (SD) average. For each subject, the SD of all three repetitions of each measurement was calculated, and then the average of these deviations was obtained in order to generate the expected SD for an average individual within the sample.

- Variation coefficient (VC). The VC was calculated by dividing intra-subject SD average by intra-subject average means. VC is a standardized variability measure that allows the comparison between data that have different means. A small VC reflects better repeatability. To facilitate its interpretation, CV was expressed as a percentage.

The comparison between measurements was carried out using Bland-Altman graphs for multiple measurements per subject, which were generated using the MedCalc 15.0 program (Mariakerke, Belgium). The differences between instruments were plotted by comparing the averages of both devices, in order to assess the agreement over the entire range of measurements. A perfect agreement implies that the difference between both instruments will be zero. The limits of agreement (LOAs) were calculated as the average difference of the measurements with each equipment $\pm 2.0 \mathrm{SD}$ of the differences; $2.00 \mathrm{SD}$ is, by definition, the range of agreement between techniques, with the lowest value indicating high level of agreement ${ }^{16}$.

\section{Results}

Thirty healthy subjects were assessed, out of which $17(60 \%)$ were females and $12(40 \%)$ were males. Average age was $28.70 \pm 8.06$ years (range: 19-49 years). 
Table 1. Comparisons between central corneal thickness measurements with the Wavelight ${ }^{\oplus}$ Ex500 pachymeter and the ultrasonic pachymeter

\begin{tabular}{|c|c|c|c|c|c|c|c|}
\hline Parameter & $\mathrm{N}$ & Wavelight ${ }^{\oplus} \mathrm{E} \times 500(\mu)$ & $\begin{array}{c}\text { Ultrasonic } \\
\text { pachymetyer }(\mu)\end{array}$ & $\begin{array}{c}\text { WL-US } \\
\text { difference }(\mu)\end{array}$ & $\mathrm{p}$ & ICC & $95 \%$ LOA \\
\hline Central corneal thickness & 30 & $553.31 \pm 32.47$ & $562.21 \pm 36.73$ & $8.90 \pm 9.03$ & $<0.001$ & 0.935 & $-9.16-26.96$ \\
\hline
\end{tabular}

Table 2. Inter-observer reproducibility of the Wavelight ${ }^{\circledR}$ EX500 pachymeter and the ultrasound pachymeter

\begin{tabular}{lc}
\hline & $\begin{array}{c}\text { Central corneal } \\
\text { thickness }(\boldsymbol{\mu})\end{array}$ \\
\hline Wavelight ${ }^{\circledast}$ EX500 & \\
Average $(\mu)$ & $553 S .31$ \\
SD $(\mu)$ & 3.41 \\
ICC & 0.991 \\
VC $(\%)$ & 4.0 \\
Ultrasound pachymeter & \\
Average $(\mu)$ & 562.21 \\
SD $(\mu)$ & 5.96 \\
ICC & 0.988 \\
VC $(\%)$ & 2.0 \\
\hline
\end{tabular}

ICC: intraclass correlation coefficient; SD: intra-subject standard deviation; VC: variation coefficient.

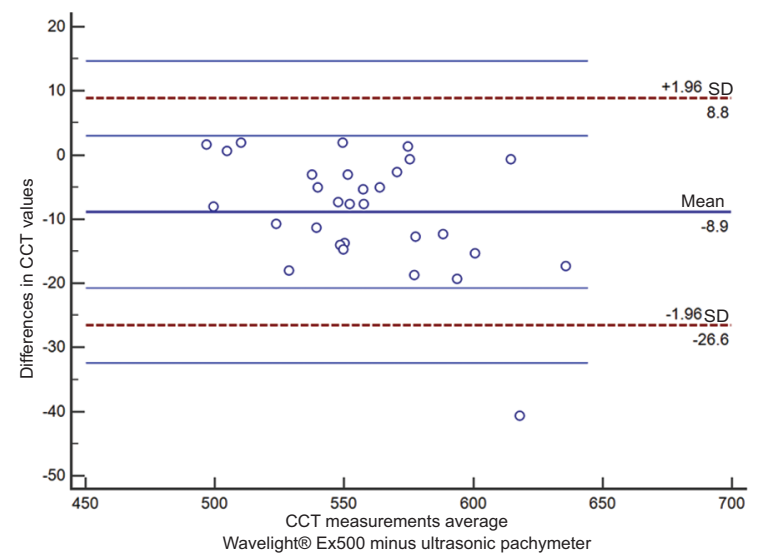

Figure 1. Bland-Altman graphs showing central corneal thickness (CCT) differences between instruments. Absolute difference between Wavelight ${ }^{\circledR}$ EX500 minus ultrasonic pachymeter values. Dotted lines indicate the mean differences $\pm 1.96 S D$ (limits of agreement), whereas the continuous horizontal line indicates differences mean value.

The studied eye was the right one in 12 patients (40\%) and the left one in $18(60 \%)$.

The difference in the CCT measurement between both instruments is shown in table 1 , which on average was $8.90 \pm 9.03 \mu(95 \%$ confidence interval: 5.52-12.27 $\mu$ ), and was statistically significant with a p-value $<0.001$ after Bonferrioni's adjustment. In no measurement were there equal values obtained: in 25 of the 30 patients, the US pachymeter had higher values than Wavelight ${ }^{\circledR}$ Ex500 (mean: $10.98 \mu$, range: $0.67-40.67 \mu$ ), and in the remaining five, the Wavelight $^{\circledR}$ Ex500 pachymeter yielded higher values (mean:
$1.53 \mu$, range: $0.67-2.00 \mu$ ), which was much lower than when the ultrasonic pachymeter had higher values.

Both instruments showed very good repeatability (Table 2), as demonstrated by a repeated measurements VC lower than $4 \%$ for each equipment. ICC was quite similar with both instruments: for Wavelight ${ }^{\circledR}$ Ex500, it was 0.99 , and for US, it was 0.98 , both within the range of excellence ${ }^{16}$. For the ICC calculation, the two-factor model with random effects was used with absolute agreement.

The agreement between measurements can be visualized by means of the Bland and Altman graphs (Fig. 1). The $95 \%$ LOA of Wavelight $₫$ Ex500 versus US pachymeter for CCT had a range of 8.8-26.6 $\mu$.

\section{Discussion}

This is the first study to assess Wavelight ${ }^{\circledR}$ Ex500 pachymeter intra-observer repeatability based on OLCR technology, as well as the agreement with the standard method, which is US pachymeter, in the measurement of CCT. These results are important, since several of the most important safety parameters in refractive surgery depend on the measurement of corneal thickness, such as preoperative pachymetry, flap thickness and residual stromal bed ${ }^{17-19}$. In our study, a statistically significant difference of $8.90 \pm 9.03 \mu$ was found, which however is not clinically significant, since it would correspond to $0.66 \mathrm{D}$ of ablation according to Munnerlyn, et al. formula ${ }^{20}$, and even less so if large optical areas are used ${ }^{1}$.

The difference found in CCT might be explained by two main reasons: the first one is due to the intrinsic difference between both technologies to measure CCT, which has been demonstrated by different studies assessing the same OLCR technology used by the Lensar LS 900 equipment (Haag Streit, Germany). Bayhan, et al. ${ }^{5}$ studied 50 healthy patients and found a slightly larger difference than that observed by us, of $13.20 \pm$ $6.46 \mu$, between US and OLCR pachymetry. Beutelspacher, et al. ${ }^{7}$ also found greater thickness with the US pachymeter in comparison with OLCR, with a difference that was more similar to ours (6.5 vs. $8.09 \mu$ ), but the 
difference in this case was not statistically significant. On the other hand, Spadea, et al. ${ }^{6}$ and Soeken, et al. ${ }^{12}$ also found a difference, but unlike our results and those of the aforementioned authors, OLCR pachymetry in their study had higher values than US pachymetry, with a difference between both of $2.4 \pm 4.5 \mu$ for the first observer and $4.0 \pm 5.2 \mu$ for the second one. A similar result was reported by Tai, et al. ${ }^{21}$, who found a difference of $3.5 \mu$. OLCR comparisons with other technologies generally have neither had very important variations, as reported by Chen, et al. ${ }^{9}$, who found greater thickness with Lensar than with Pentacam $(-4.29 \pm$ $5.69 \mu$ ), and by Beutelspacher, et al. ${ }^{7}$, who found that OLCR yielded the lowest values when compared to Orbscan, Visante and the ultrasonic pachymeter.

The second probable reason for the difference in results is that it is not possible to ensure that the place of measurement is the same. To try to reduce this source of error, we performed both measurements using the Wavelight ${ }^{\circledR}$ Ex500 stretcher and the fixation light as a guide for the centering of the US pachymeter measurement, since that was the OLCR-measured area. This might also explain the SD difference found between subjects, which was larger with the US pachymeter than with Wavelight ${ }^{\circledR}$ Ex500, in addition to the sources of error due to a higher pressure or non-perpendicular alignment of the ultrasound probe.

Through the Bland-Altman graphs, we can observe that both instruments have high agreement and small difference; in addition, ICC with both instruments is very similar to that found by Koktekir, et al. ${ }^{22}$, who compared the Lensar OLCR with the ultrasound pachymeter and found an ICC of $99.3 \%$, in comparison to our $93.5 \%$. Both results are rated as excellent.

As regards measurement reproducibility with both instruments, the results were very good and similar, a little better with OLCR than with the ultrasound pachymeter, which was similar to findings by other authors, such as Spadea, et al. ${ }^{6}$

In conclusion, our results show that the pachymeter included in Wavelight ${ }^{\circledR}$ Ex500 Excimer Laser is a good alternative to ultrasound pachymetry in healthy patients, and since it is a non-contact technique, it is a safer option for CCT transoperative measurement.

\section{Ethical responsibilities}

Protection of people and animals. The authors declare that the procedures followed adhered to the ethical standards of the human experimentation responsible committee and were in accordance with the World Medical Association and the Declaration of Helsinki.

Confidentiality of data. The authors declare to have followed the protocols of their working center on the publication of patient data.

Right to privacy and informed consent. The authors have obtained informed consent from the patients or subjects referred to in the article. This document is in possession of the corresponding author.

\section{Funding}

There was no funding source.

\section{Conflict of interests}

The authors declare not having any conflicts of interests.

\section{References}

1. Chang AW, Tsang AC, Contreras JE, Huynh PD, Calvano CJ, Crnic-Rein TC, et al. Corneal tissue ablation depth and the Munnerlyn formula. J Cataract Refract Surg. 2003;29:1204-10.

2. Wang SY, Melles R, Lin SC. The impact of central corneal thickness on the risk for glaucoma in a large multiethnic population. J Glaucoma. 2014; 23:606-12.

3. Steinberg J, Mehlan J, Frings A, Druchkiv V, Richard G, Katz T, et al. [Pachymetry and intraocular pressure measurement by corneal visualization Scheimpflug technology (Corvis ST): a clinical comparison to the gold standard.] Ophthalmologe. 2015;112:770-7.

4. Miglior S, Albe E, Guareschi M, Mandelli G, Gomarasca S, Orzalesi N. Intraobserver and interobserver reproducibility in the evaluation of ultrasonic pachymetry measurements of central corneal thickness. Br J Ophthalmol. 2004;88:174-7.

5. Bayhan HA, Aslan Bayhan S, Can I. Comparison of central corneal thickness measurements with three new optical devices and a standard ultrasonic pachymeter. Int J Ophthalmol. 2014;7:302-8.

6. Spadea L, Giammaria D, Di Genova L, Fiasca A. Comparison of optical low coherence reflectometry and ultrasound pachymetry in the measurement of central corneal thickness before and after photorefractive keratectomy. J Refract Surg. 2007;23:661-6.

7. Beutelspacher SC, Serbecic N, Scheuerle AF. Assessment of central corneal thickness using OCT, ultrasound, optical low coherence reflectometry and Scheimpflug pachymetry. Eur J Ophthalmol. 2011;21:132-7.

8. Shen P, Ding X, Congdon NG, Zheng Y, He M. Comparison of anterior ocular biometry between optical low-coherence reflectometry and anterior segment optical coherence tomography in an adult Chinese population. J Cataract Refract Surg. 2012;38:966-70.

9. Chen W, McAlinden C, Pesudovs K, Wang Q, Lu F, Feng Y, et al. Scheimpflug-Placido topographer and optical low-coherence reflectometry biometer: repeatability and agreement. J Cataract Refract Surg. 2012;38:1626-32.

10. López-Miguel A, Correa-Pérez ME, Miranda-Anta S, Iglesias-Cortinas D, Coco-Martín MB, Maldonado MJ. Comparison of central corneal thickness using optical low-coherence reflectometry and spectral-domain optical coherence tomography. J Cataract Refract Surg. 2012;38:758-64.

11. Huerva V, Ascaso FJ, Soldevila J, Lavilla L. Comparison of anterior segment measurements with optical low-coherence reflectometry and rotating dual Scheimpflug analysis. J Cataract Refract Surg. 2014; 40:1170-6.

12. Soeken TA, Apsey DA, Townley JR, Haas RW, Caldwell MC. Comparison of pachymetry measurements between the Alcon Wavelight EX500 and Sonogage Corneo-Gage Plus platforms. J Cataract Refract Surg. 2015;31:328-32.

13. Read SA, Collins MJ. Diurnal variation of corneal shape and thickness. Optom Vis Sci. 2009;86:170-80. 
14. Asensio I, Rahhal SM, Alonso L, Palanca-Sanfrancisco JM, Sanchís-Gimeno JA. Corneal thickness values before and after oxybuprocaine $0.4 \%$ eye drops. Cornea. 2003;22:527-32.

15. Herse P, Siu A. Short-term effects of proparacaine on human corneal thickness. Acta Ophthalmol. 1992;70:740-4.

16. Kramer MS, Feinstein AR. Clinical biostatistics. LIV. The biostatistics of concordance. Clin Pharmacol Therapeut. 1981;29:111-23.

17. Randleman JB, Trattler WB, Stulting RD. Validation of the Ectasia Risk Score System for preoperative laser in situ keratomileusis screening. Am J Ophthalmol. 2008;145:813-8.

18. Santhiago MR, Smadja D, Gomes BF, Mello GR, Monteiro ML, Wilson SE, et al. Association between the percent tissue altered and post-laser in situ keratomileusis ectasia in eyes with normal preoperative topography. Am J Ophthalmol. 2014;158:87-95.e81.
19. Ambrosio R Jr, Dawson DG, Belin MW. Association between the percent tissue altered and post-laser in situ keratomileusis ectasia in eyes with normal preoperative topography. Am J Ophthalmol. 2014;158:1358-9.

20. Munnerlyn CR, Koons SJ, Marshall J. Photorefractive keratectomy: a technique for laser refractive surgery. J Cataract Refract Surg. 1988;14:46-52.

21. Tai LY, Khaw KW, Ng CM, Subrayan V. Central corneal thickness measurements with different imaging devices and ultrasound pachymetry. Cornea. 2013;32:766-71.

22. Koktekir BE, Gedik S, Bakbak B. Comparison of central corneal thickness measurements with optical low-coherence reflectometry and ultrasound pachymetry and reproducibility of both devices. Cornea. 2012;31:1278-81. 